\title{
Global change at the Paleocene-Eocene boundary: climatic and evolutionary consequences of tectonic events
}

\author{
David K. Rea, James C. Zachos, Robert M. Owen and Philip D. Gingerich \\ Department of Geological Sciences, The University of Michigan, Ann Arbor, MI 48109-1063, U.S.A.
}

(Received August 7, 1989; revised and accepted January 22, 1990)

\begin{abstract}
Rea, D. K., Zachos, J. C., Owen, R. M. and Gingerich, P. D., 1990. Global change at the Paleocene-Eocene boundary: climatic and evolutionary consequences of tectonic events. Palaeogeogr., Palaeoclimatol., Palaeoecol., 79: 117-128.

Events of the Paleocene-Eocene boundary provide the clearest example to date of how a tectonic event may have global climatic consequences. Recent advances permit well-constrained stratigraphic determination of several events that occurred at that boundary, in chron C24R: a many-fold increase in sea-floor hydrothermal activity, a global warming, a reduction in the intensity of atmospheric circulation, a conversion to salinity-driven deep ocean circulation, a marked lightening of oceanic $\delta^{13} \mathrm{C}$ values, extinction and evolution of both benthic foraminifera and land mammals, and important plate-boundary reorganizations including the outpouring of the east Greenland volcanics and the initiation of the oceanic rift between Norway and Greenland.

We hypothesize that enhanced sea-floor hydrothermal activity occasioned by global tectonism resulted in a flooding of the atmosphere with $\mathrm{CO}_{2}$, causing a reduced pole-to-equator temperature gradient and increased evaporation at low latitudes. Increased formation of warm, salty, probably low-nutrient waters coupled with the warm temperatures at high latitudes occasioned a salinity-driven, rather than temperature-driven, deep-water circulation. This newly-evolved ocean circulation pattern changed the apportionment of global heat transport from the atmosphere to the ocean, with concomitant changes in the circulation intensity of both. Reduced intensity of atmospheric circulation resulted in lower oceanic biological productivity and enhanced seasonality of climate on the continents. A major extinction event among benthic foraminifera was probably a response to the new low-nutrient and chemically changed bottom waters, and endemism following rapid evolution and dispersal of mammalian orders may have been in response to the new continental climate regime.
\end{abstract}

\section{Introduction}

Paleoceanographers have long accepted the idea that tectonism is of paramount causal importance on timescales of climate change longer than a few hundred thousand years. A combination of insolation, continental and oceanic configuration, and atmospheric chemistry determines the pole-toequator temperature gradient. The Earth's fluid envelope, the atmosphere and ocean, moves in response to this planetary temperature gradient, and is responsible in turn for the climatic regime of any area and era. Oceanic circulation is constrained by continental configuration, but presumably atmospheric circulation is less so.
We know about continental rearrangements resulting in the opening of oceanic gateways such as Australia-Antarctica and the closing of others, such as Tethys (Berggren and Hollister, 1977; Scotese et al., 1988). Some of these rearrangements appear to have clear paleoclimatic consequences, such as the establishment of a deep-water passage between Australia and Antarctica prior to the earliest Oligocene ice build up on Antarctica (Kennett, 1977). Others do not. For example, paleoceanographers were tempted to link the closing of the Isthmus of Panama at about 3.2 Ma (Keigwin, 1982) to the onset of major Northern Hemisphere glaciation. However, more careful stratigraphic work has shown that the input of 
glacially related clastics in both the North Atlantic (Shackleton et al., 1984a) and North Pacific (Rea and Schrader, 1985) began about 2.4 or $2.5 \mathrm{Ma}$ and was coincident with a pronounceed shift in the $\delta^{18} 0$ record indicative of ice-volume growth (Prell, 1982; Thunell and Williams, 1983). Thus, Northern Hemisphere glaciation began about 700,000 years after the closing of the Isthmus of Panama. We learn from this Pliocene paleoclimatology lesson that drawing upon the tectonicallybased gateway hypothesis to explain climate change requires careful stratigraphic analysis of the pertinent proxy indicators.

In addition to the opening and closing of oceanic gateways, which effect global transport paths of heat and moisture, the chemistry, especially the $\mathrm{CO}_{2}$ content, of oceans and atmospheres changes on tectonic timescales in response to sea-floor hydrothermal activity (Berner et al., 1983) and to volcanism (Arthur et al., 1985). Both hydrothermal activity (Owen and Rea, 1985; Rea and Leinen, 1986; Lyle et al., 1987; Olivarez and Owen, 1989) and volcanism (Rea and Vallier, 1983; White and McKenzie, 1989) are much more intense during times of continental rifting and oceanic plate boundary rearrangements; the geochemical consequences of these tectonic events, which include the $\mathrm{CO}_{2}$ budget (Owen and Rea, 1985), may even be reflected in the biosphere (Rich et al., 1986).

\section{Events of the Paleocene-Eocene boundary}

\section{Environmental changes}

Several pronounced changes in global environment occurred near the time of the PaleoceneEocene boundary at about $57 \mathrm{Ma}$ (timescale of Berggren et al., 1985). In considering these events, the stratigraphic position of this boundary, in foraminifer zone P6, nannofossil zone NP10 (Berggren et al., 1985), at or near the Clarkforkian-Wasatchan land-mammal age boundary (Gingerich, 1980, 1989a; Butler et al., 1987), and within magnetochron C24R (Aubry et al., 1988), is more important than the assignment of a numerical age.

The several oceanic and climatic events that occur during chron C24R include: an order of magnitude increase in the mass accumulation rate of hydrothermal sediments (Olivarez and Owen, 1989); a large decrease in the grain size of eolian dust, interpreted as a reduction in the intensity of atmospheric circulation, the largest such change in the entire Cenozoic (Janecek and Rea, 1983; Janecek, 1985; Rea et al., 1985); the greatest Cenozoic excursion in carbon isotopic values, a rapid lightening of the oceanic $\delta^{13} \mathrm{C}$ values by about 2.5\% (Shackleton and Hall, 1984; Oberhansli and Toumarkine, 1985; Shackleton, 1986, 1987); an oceanic warming indicated by studies of calcareous plankton (Haq et al., 1977); and a lightening of benthic $\delta^{18} 0$ values of about $0.5-1 \%$ at about the time of the Paleocene-Eocene boundary (Shackleton and Boersma, 1981; Oberhänsli and Toumarkine, 1985; Shackleton, 1986; Miller et al., 1987; Prentice and Matthews, 1988). Benthic foraminifera, relatively untouched by the events of the Cretaceous-Tertiary boundary, underwent a significant extinction event at the PaleoceneEocene boundary (Tjalma and Lohmann, 1983; Miller et al., 1987; Thomas, in press). On land, mammals show a major pulse of extinctionorigination turnover at the Paleocene-Eocene boundary, which appears to correspond to climatic changes then (Gingerich, 1980, 1987, 1989a).

\section{Tectonic events and sea-floor hydrothermal activity}

Marine geologists have known for 20 years or more that the earlier portion of the Eocene was a time of plate boundary rearrangement (Hayes and Pitman, 1970; Rona and Richardson, 1978). More recent work on the timing of plate boundary realignments in the Pacific Basin (Rea and Dixon, 1983; Caress et al., 1988) has shown the early Eocene to be an important time of change in patterns of spreading centers and transform faults. In the high North Atlantic, ocean-floor drilling and dating of continental margin volcanic rocks has demonstrated that the Norwegian-Greenland sea opened and the vast east Greenland volcanics erupted during this time, chron C24R (Roberts et al., 1984; White and McKenzie, 1989). Comparison of spreading rates among different basins (Aubry et al., 1988) identifies the earliest Eocene, especially chron C24R, as a time of important changes in ridge crest tectonism. 
Leg 92 of the Deep Sea Drilling Project demonstrated that the amount of sea-floor hydrothermal activity is not related to the rate of seafloor spreading, but undergoes large, commonly order of magnitude, increases during times of changes in the tectonic regime of the spreading center - ridge jumps, ridge-transform realignments, etc. (Owen and Rea, 1985; Rea and Leinen, 1986; Lyle et al., 1986, 1987). This relationship, first documented for the southeast Pacific, has been confirmed in the North Atlantic where DSDP Site 549 shows clear geochemical evidence of a one to two order of magnitude increase in hydrothermal activity at the Paleocene-Eocene boundary in nannofossil zone NP10 and foraminifer zone P6, the time of the opening of the Norwegian-Greenland sea (Fig. 1; Olivarez and Owen, 1989). Cores from the North and South Pacific also contain evidence of enhanced input of hydrothermallyderived sediment during the early Eocene (Leinen and Stakes, 1979; Leinen, 1987).

Hydrothermal activity along the world's midocean ridge system now supports about $20 \%$ of the pre-industrial level of atmospheric $\mathrm{CO}_{2}$ as every

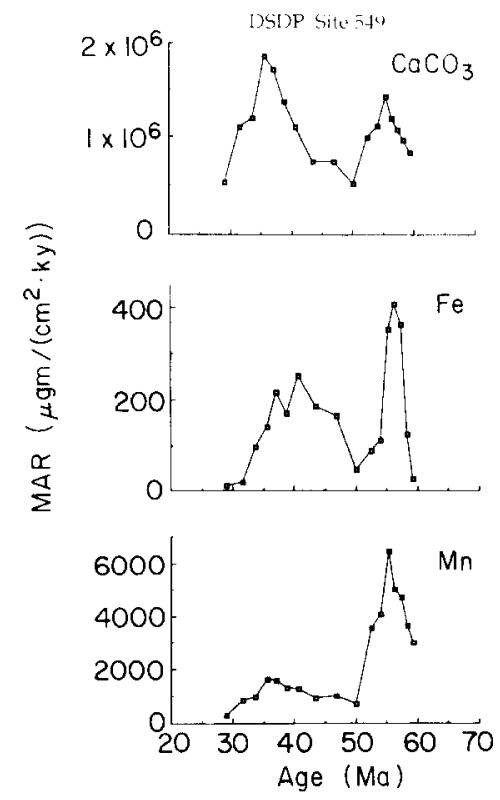

Fig. 1. Mass fluxes of hydrothermally related materials to DSDP Site 549 , northeastern Atlantic Ocean $\left(49^{\circ} 05^{\prime} \mathrm{N}, 13^{\circ} 06^{\prime} \mathrm{W}\right)$. Older maxima occur in foraminifer zone P6 and nannofossil zone NP10, at the Paleocene-Eocene boundary (Olivarez and Owen, 1989). mole of $\mathrm{Ca}$ emitted in the exiting hydrothermal fluids reacts with oceanic bicarbonate to produce $\mathrm{CaCO}_{3}$ and $\mathrm{CO}_{2}$ (Owen and Rea, 1985). Thus an order of magnitude increase in the amount of hydrothermal activity has the potential to significantly increase global $\mathrm{CO}_{2}$ levels. Owen and Rea (1985) suggested that this process occurred in the early Eocene and thus explained a number of oceanic and sedimentary phenomena and the globally warm climates then.

\section{Oceanic and atmospheric circulation in the early Eocene}

Recently reported results from high-latitude ocean floor drilling in the southern Atlantic (Kennett and Stott, 1989) and Indian (Zachos et al., 1989b) Oceans document an important change in the style of deep-ocean circulation that began at the Paleocene-Eocene boundary. Oxygen-isotopic data from benthic and planktic foraminifera show that the planetary temperature gradient was reduced during the early Eocene to a greater extent than previously recognized (Fig.2: Barron, 1987). Further, Kennett and Stott (1989) and Zachos et al. (1989b) suggest that the oceans may have been characterized by warm, saline bottom water that formed under the sub-tropical highs, perhaps in the Tethys, and moved poleward in the deep ocean. In the past, this sort of salinity-driven ocean circulation has been postulated for the warm Cretaceous (Brass et al., 1982). However, Woodruff and Savin (1989) have demonstrated that warm, saline waters may have been a significant component of ocean deep waters as recently as the early Miocene.

The largest Cenozoic excursion in carbon isotopic values of oceanic calcite, a rapid lightening of about $2.5 \%$ observed in both benthic and planktic materials, also occurred in the lowermost Eocene (Shackleton and Hall, 1984; Shackleton, 1986, 1987). Carbon isotopic values were positive through most of upper Paleocene sediments; the sharp decline occurred at the end of that time period (Fig.2).

Benthic foraminifera generally were unaffected by events of the Cretaceous-Tertiary boundary. These organisms were subjected to a widespread 
Low to High Latitude and Vertical Paleotemperature and Carbon Isotope Gradients

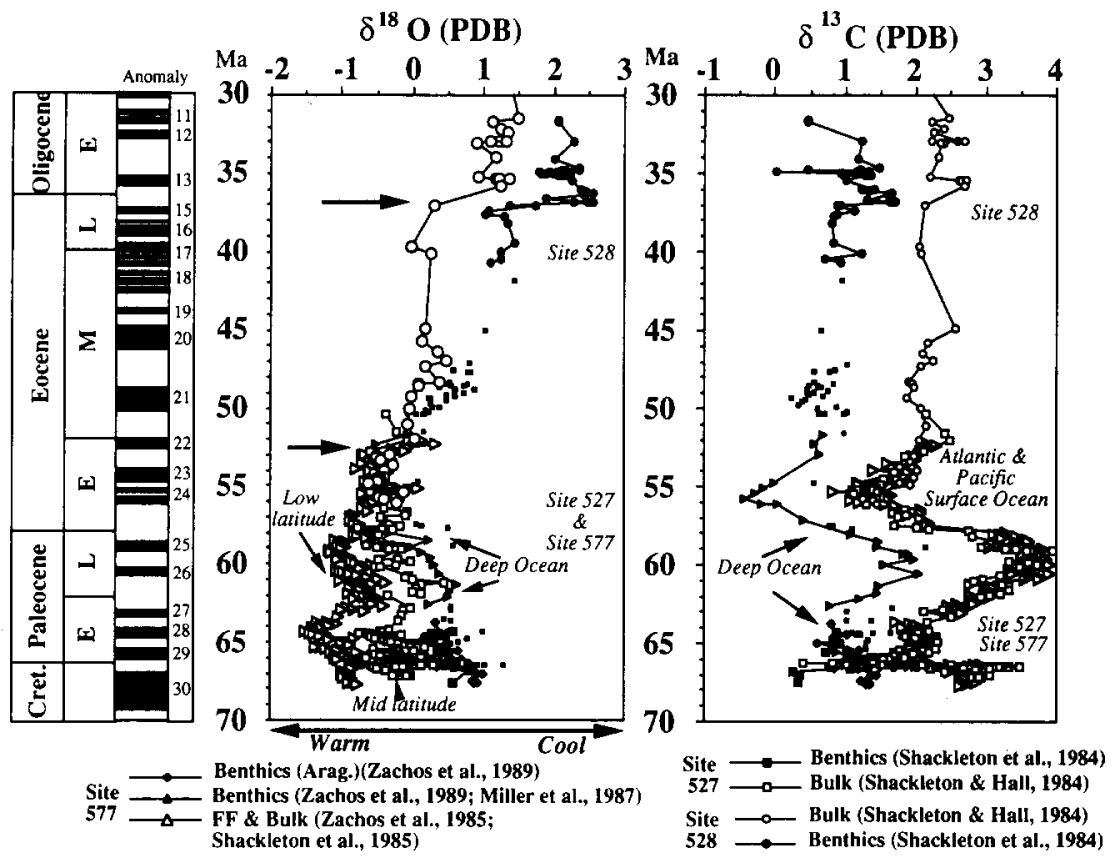

Fig.2. A 40 million-year long record of oxygen and carbon isotope composition and paleotemperatures compiled from published data from DSDP sites 527 and 528 on the Walvis Ridge in the South Atlantic and site 577 on Shatsky Rise in the North Pacific. The fine fraction or bulk samples (open symbols) are predominantly coccoliths and are considered to be representative of surface (low to midlatitude) conditions. Benthic foraminiferal values (filled symbols) are representative of bottom water conditions. During the early Eocene the surficial and bottom $\delta^{18} 0$ values coincide, indicative of low planetary temperature gradients.

extinction event near the end of the Paleocene. Recent reports by Miller et al. (1987) and by Thomas (in press) show these extinctions to have occurred in zone P6, at the Paleocene-Eocene boundary.

Changes in the grain size of eolian dust indicate that the intensity of atmospheric circulation was reduced several fold at the Paleocene-Eocene boundary, from zonal winds as strong as today's in the latest Cretaceous and Paleocene to apparently quite sluggish winds in the Eocene (Fig.3; Janecek and Rea, 1983; Janecek, 1985; Rea et al., 1985). This observation was difficult to reconcile with the general understanding of the Cenozoic as a time of transition, a cooling from the Cretaceous warmth to the late Cenozoic glacial ages with appropriate increases in the circulatory vigor of both atmospheres and oceans (Rea et al., 1985; Barron, 1987).

Two cores raised from the North Pacific Ocean permit examination of stratigraphic details of the events of the Paleocene-Eocene boundary. Core LL44-GPC3 contains a pelagic clay sequence that records both the order of magnitude increase in the flux of hydrothermal materials and the change in grainsize of eolian dust (Fig.4). Information from LL44-GPC3 presented by Leinen (1987) allows calculation of fluxes of the hydrothermal components to this site, far from the early Eocene spreading center. These fluxes, and indications of hydrothermal input determined from multivariate analyses (Leinen, 1987), reach a maximum at the same horizon as the change in eolian grain size (Fig.4). Farther west at DSDP Hole 577, sediments of the Paleocene-Eocene boundary are calcareous oozes. Miller et al. (1987) examined this core and showed that the change in dust grain size, the shift in oxygen isotopes, the shift in carbon isotopes, and the foraminifer extinction event all occur at the Paleocene-Eocene boundary, in foram zone P6 and chron C24R (Fig.5). Thus we are confident of 


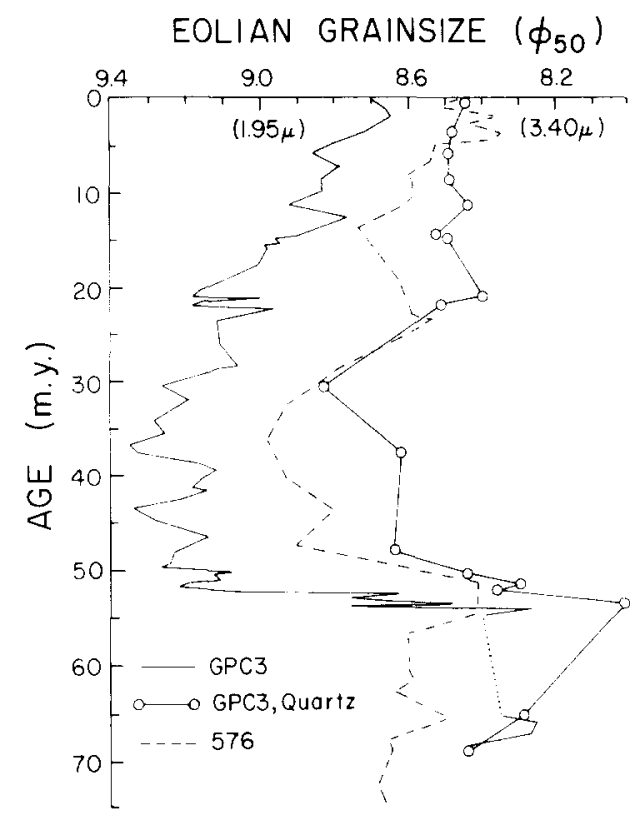

Fig.3. Size of eolian grains extracted from North Pacific pelagic clay cores LL44-GPC3 $\left(32^{\circ} 20^{\prime} \mathrm{N}, 157^{\circ} 50^{\prime} \mathrm{W}\right)$ and DSDP 576 $\left(32^{\circ} 21^{\prime} \mathrm{N}, 164^{\circ} 17^{\prime} \mathrm{E}\right)$, and of quartz grains isolated from GPC3. The large change near 50-55 Ma (but dated with ichthyoliths) indicates a several-fold reduction in the intensity of atmospheric circulation (after Rea et al., 1985).

our stratigraphy; the several events have been recorded in the same cores, not just in the same fossil zone or magnetochron.

\section{Terrestrial floral and faunal changes during the early Eocene}

Fossil plant assemblages from maritime climates indicate the earliest Eocene to be the warmest climate of the Cenozoic (Hubbard and Boulter, 1983; Wolfe, 1989). Plant assemblages from continental interiors suggest changes to a drier climate at the time of the Paleocene-Eocene boundary, perhaps with increased seasonality (Wolfe, 1978, 1989).

Most of the modern orders of mammals appeared during a brief period of the earliest Eocene (Gingerich, 1987). The best information on mammalian evolution for this time period comes from the Western Interior of North America, where these events occur in deposits of Clarkforkian and early Wasatchian age (Rose, 1981; Gingerich, 1989a). Magnetostratigraphic analysis of fossil- bearing sections show the Clarkforkian and lower Wasatchian sediments to have been deposited during polarity chron C24R (Butler et al., 1981, 1987).

Two examples of sudden changes in mammalian fauna that occurred within chron C24R at the Paleocene-Eocene boundary are illustrated on Fig.6. Both can be related to global climate change. Allometry of metabolic physiology determines the limits of body size in mammals; incompensable heat loss to the environment sets a lower limit and uncontrollable heat gain sets an upper limit. All else being equal, which is the case when closely-related species closely spaced in time and living in the same place are compared, this means that both the smallest and largest mammals will be larger during times of cooler climate and smaller during times of warmer climate. The smallest mammals are poorly sampled in the fossil record and thus of little value for this discussion, and the size of mammals in the intermediate range is complexly determined by many coevolutionary factors in addition to temperature. The largest mammals are usually well sampled in the fossil record, and there is no reason why the largest mammals should become smaller that is not, directly or indirectly, related to the ambient environmental temperature.

The largest Clarkforkian and Wasatchian mammal, Coryphodon, became rapidly smaller and then larger during chron C24R, declining from an average body mass of $800 \mathrm{~kg}$ to $400 \mathrm{~kg}$ before getting larger again (Gingerich, 1989b). This tendency parallels a change in oxygen isotopic values of $\mathrm{C} 24 \mathrm{R}$ planktonic foraminifera in Antarctic surface waters, which corresponds to a change of $4-5^{\circ} \mathrm{C}$ (Fig.6A; Shackleton and Boersma, 1981; Stott et al., in press). This is the environmental temperature difference predicted for a $50 \%$ decrease in the size of a temperature-limited largest mammal (Alexander, 1989) and implies a mid-continent warming of that amount. Thus both continental and marine records show a consistent pattern of global warming during chron C24R.

Results of a principal component analysis of family-level mammalian faunal composition for faunas spanning the Clarkforkian-Wasatchian boundary are shown on Fig.6B. Clarkforkian and 


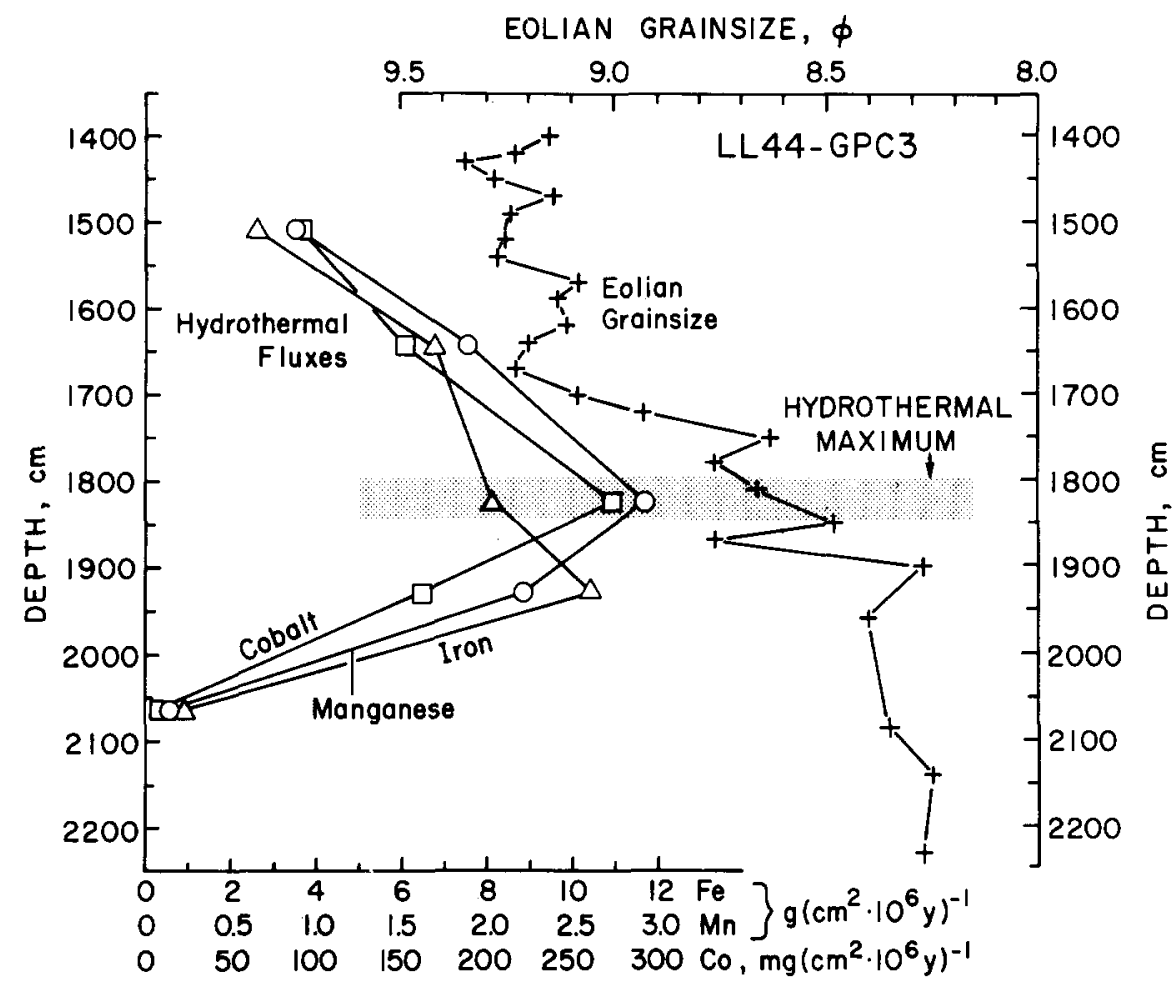

Fig.4. Hydrothermal and eolian data from North Pacific core LL44-GPC3 (30 $\left.20^{\prime} \mathrm{N}, 157^{\circ} 50^{\prime} \mathrm{W}\right)$. Fluxes of selected hydrothermal materials and level of maximum hydrothermal component (shaded) as indicated by multivariate analyses conducted by Leinen (1987). Eolian grain size data from Janecek and Rea (1983). The depths (thus timing) of the hydrothermal maximum and of the change in dust size coincide.

Wasatchian faunas are distinctly different on the basis of the first principal component, which accounts for $71 \%$ of the total variance in the assemblage (Gingerich, 1989a). The pulse of faunal turnover separating the two assemblages was short and faunal change was relatively rapid. We note that this turnover event occurs $200 \mathrm{~m}$ below the Coryphodon dwarfing event in the same stratigraphic section, denoting complexity in the nature of mammalian faunal change in chron $\mathrm{C} 24 \mathrm{R}$.

\section{The hypothesis}

The primary event that triggered climatic shifts at the Paleocene-Eocene boundary and the biotic responses to them was the change in the tectonic regime of mid-ocean ridges documented most recently by Aubry et al. (1988) and by White and Mackenzie (1989). Sea-floor tectonism resulted in increased levels of hydrothermal activity (Leinen and Stakes, 1979; Lyle et al., 1986, 1987; Leinen, 1987; Olivarez and Owen, 1989) and a $\mathrm{CO}_{2}-$ induced global warming (Owen and Rea, 1985).

Computer models of modern $\mathrm{CO}_{2}$-induced warming scenarios show relatively greater polar warming, an effect which would further reduce the already low pole-to-equator temperature gradient of the latest Paleocene. The combination of warm subpolar regions and increased evaporation in the subtropics had a marked effect on the nature of deep ocean circulation. Suddenly the densest water was the warm and salty, low-nutrient water from the subtropical gyres rather than the correspondingly more fresh, almost as warm, waters from higher latitudes (Kennett and Stott, 1989; Zachos et al., 1989b). With the reversal of ocean deep circulation to a salinity-driven process, the ocean became the significant transporter of heat to high latitudes. Assuming little change in the pole to equator temperature gradient (Barron, 1987; 


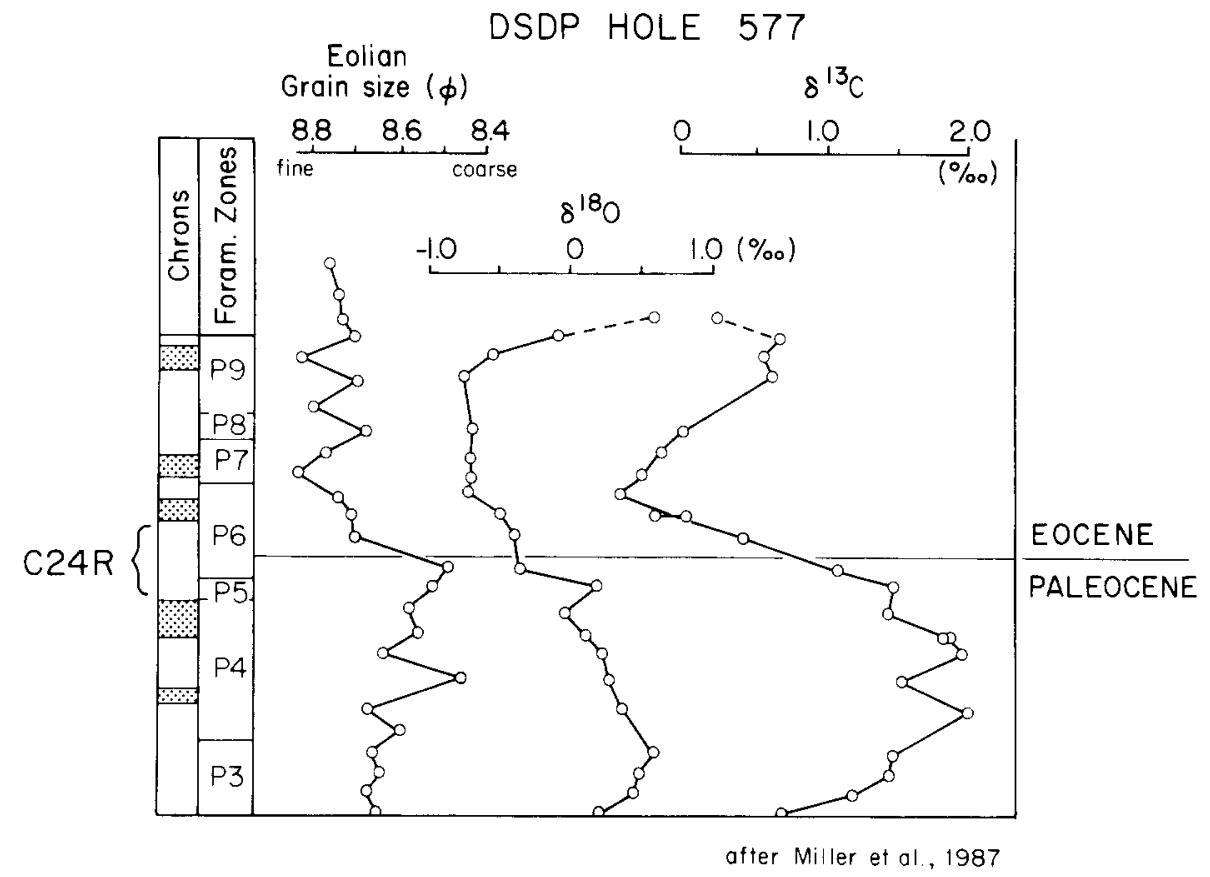

Fig.5. Data from North Pacific core DSDP $577\left(32^{\circ} 27^{\prime} \mathrm{N}, 157^{\circ} 43^{\prime} \mathrm{E}\right)$ showing that the change in eolian grain size, the shift in oxygen isotopes and the rapid lightening of carbon isotopic values all occur in foraminiferal zone P6 and chron C24R (after Miller et al., 1987).

Covey and Barron, 1988), the atmosphere no longer was the primary transporter of heat, and thus its circulatory vigor was greatly diminished (Janecek and Rea, 1983; Rea et al., 1985; Covey and Barron, 1988).

The several-fold reduction in the intensity of atmospheric circulation resulted in a reduction in the intensity of sea-surface circulation with a concomitant lessening of biological productivity (Rea et al., 1990). The decline in productivity may be partially reflected in the large shift in $\delta^{13} \mathrm{C}$ values (Shackleton, 1986, but see Discussion below) that occurred over exactly the same time span as the change in wind intensity (Fig.5; Miller et al., 1987), and may, in combination with the new supply of warm, low dissolved oxygen, lownutrient bottom water, have occasioned the several extinctions among the benthic foraminifera.

Continental climates became warmer in high latitude and maritime regions. Inland, an additional effect of reduced intensity of the zonal winds was to enhance the natural tendency of those regions towards seasonality (Sloan and Barron, 1989). This new climatic regime appears to have been favorable to the evolution of modern from archaic orders of mammals (Gingerich, 1980, 1987, 1989a).

\section{Discussion}

\section{Carbon isotopes and carbon reservoirs}

The above scenario for the events of the Paleocene-Eocene boundary and how they are portrayed in the geologic record all fits together with the exception of our understanding of the carbon isotopic record. Both benthic and planktic calcareous organisms record the $2.0-2.5 \%$ lightening of $\delta^{13} \mathrm{C}$ values in younger sediments across the Paleocene-Eocene boundary (Fig.2). This implies that the causal process is carbon transfer between the whole ocean and some other, presumably sedimentary, reservoir rather than an ocean-ocean or surface water-deep water fractionation. Eroding isotopically-light organic carbon from sediments and transporting it to the ocean would cause the $\delta^{13} \mathrm{C}$ values of the ocean to become lighter. Alternatively, removal of organic carbon from the 


\section{PALEOCENE-EOCENE CORYPHODON}

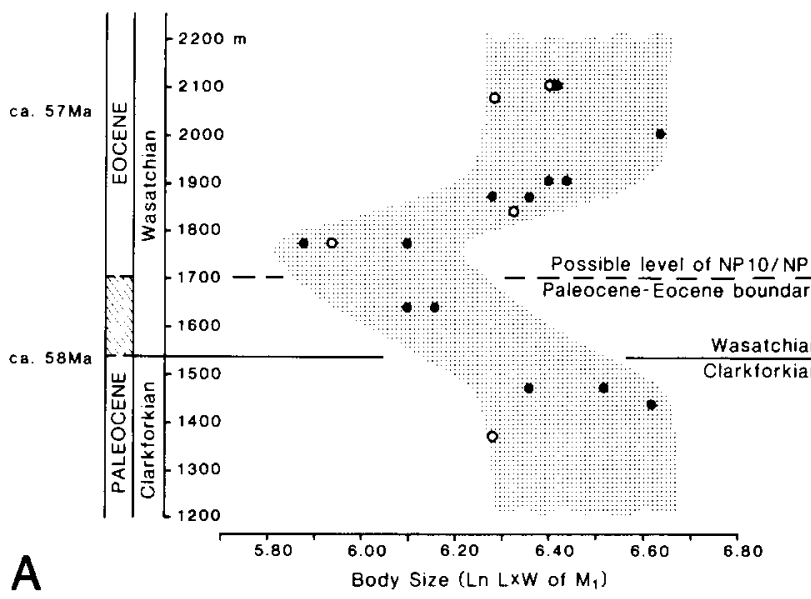

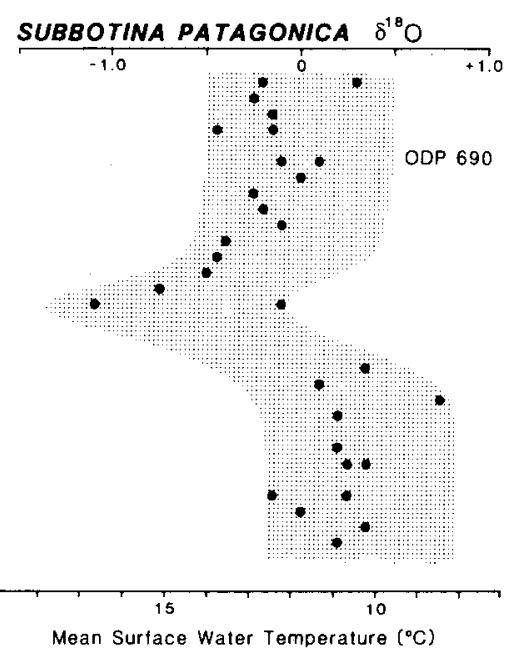

Mean Surface Water Temperature $\left({ }^{\circ} \mathrm{C}\right)$

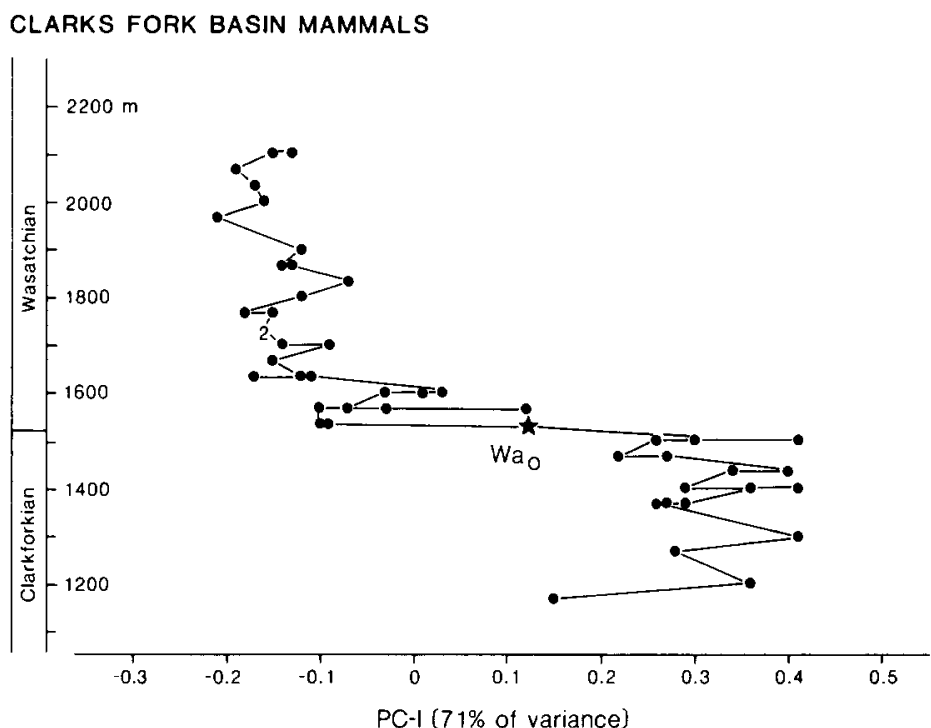

Fig.6. Mammalian response to climate change at the Paleocene-Eocene boundary. (A) Size decrease of Coryphodon from about 800 to $400 \mathrm{~kg}$ (Gingerich, 1989b) corresponding to a warming of $4-5^{\circ} \mathrm{C}$ in chron C24R (Alexander, 1989) compared to oxygen-isotopic evidence for sea-surface warming of about $5^{\circ} \mathrm{C}$ at the same time. (B) First principal component of mammalian faunal composition across the Clarkforkian-Wasatchian boundary. Stable mammalian assemblage of the uppermost Clarkforkian changed rapidly to that of the lowermost Wasatchian during chron C24R (Gingerich, 1989a).

marine environment to sediments results in heavier carbon isotopic values for oceanic carbonates. For example, the large carbon isotope shift at the Paleocene-Eocene boundary implies significant sequestering of organic carbon in upper Paleocene deposits and/or its release back to the ocean in the earliest Eocene (Shackleton, 1987).

The nature of these lower Cenozoic carbon reservoirs is not apparent. The Ronov data (Ronov et al., 1978) suggest that there is more coal in Eocene and Oligocene sediments than in the Paleocene, which would produce an effect on oceanic carbon isotopes opposite that observed. Arthur et al. (1985) have shown that positive peaks in Cretaceous carbon isotopic records occur during times of black shale deposition, but we have no 
oceanic record of Paleocene black shales. Sea-level changed very little at the time of the PaleoceneEocene boundary (Haq et al., 1987), so the exposure of continental shelves and a transfer of carbon stored thereupon (Berger et al., 1981) apparently did not play a role in this instance.

A plausible suggestion is that the early Eocene global warming caused evaporation to increase, thus there must be an overall, though of uneven distribution, increase in rainfall. The increase in rainfall, higher temperatures and $p \mathrm{CO}_{2}$ would have caused increased physical and chemical erosion of and runoff from continents, the physical record of which lies in the greatly enhanced deposition rate of clastic material in near-margin areas during the early Eocene (Thiede et al., 1980, 1981). We must assume that this erosive episode brought the organic carbon from continental soils to the seas and thus changed the carbon isotopic signature of the ocean. Furthermore, this process would also supply the carbon needed (as $\mathrm{HCO}_{3}^{-}$) to react with the hydrothermal $\mathrm{Ca}^{2+}$ in order to generate $\mathrm{CO}_{2}$.

\section{Geologic record of the Paleocene-Eocene boundary}

The litho- and bio-stratigraphic markers which define the Paleocene-Eocene epoch boundary were essentially created by the events discussed in this paper. Tectonically-caused changes in climate bring about changes in oceanic circulation and the climates of the continental surfaces. The biosphere responds to these stimuli with episodes of extinction and evolution.

Other epoch boundaries in the Cenozoic may also have an ultimately tectonic cause. The events of the Eocene-Oligocene boundary have been known for some time to have been the result of the separation of Australia from Antarctica which forced changes in oceanic circulation and global heat transport (Kennett, 1977; Berggren and Hollister, 1977). More recently it has been suggested that the Pliocene uplift of the two broad elevations of the Northern Hemisphere, the Himalayas and the Colorado Plateau, was responsible for the important changes in atmospheric circulation which occasioned the onset of Northern
Hemisphere glaciation (Ruddiman and Kutzbach, 1989; Kutzbach et al., 1989).

On timescales of a half million years or longer, important changes in global climate, some of which are great enough to form epoch boundaries, are often the direct consequence of a tectonic event. These events force a change in the circulation of the ocean or atmosphere, to which the other fluid responds in order to maintain a reasonable planetary temperature gradient. Changes in the climate systems of the ocean and atmosphere have direct physical and biological consequences to the planet, which we observe in the various proxies.

\section{Acknowledgements}

We thank W.A. Berggren and two anonymous reviewers for useful comments. Most of the material discussed in this paper was first presented in a symposium held at the Spring American Geophysical Union Meeting in May of 1989. In addition to the authors, Lisa Sloan, Jim Kasting and Jack Wolfe participated in that session. Eric Barron, Ken Miller and Nick Shackleton first provided many of the clues that led to this unravelling of the events of the Paleocene-Eocene boundary. Work on the eolian component of deepsea sediments at the University of Michigan has been funded by both the Ocean Sciences (Marine Geology and Geophysics Program) and Atmospheric Sciences (Climate Dynamics Program) divisions of the National Science Foundation.

\section{References}

Alexander, R. M., 1989. Dynamics of Dinosaurs and Other Extinct Giants. Columbia Univ. Press, New York, N.Y., $167 \mathrm{pp}$.

Arthur, M. A., Dean, W. E. and Schlanger, S. O., 1985 Variations in the global carbon cycle during the Cretaceous related to climate, volcanism, and changes in atmospheric $\mathrm{CO}_{2}$. In: E. T. Sundquist and W. S. Broecker (Editors), The Carbon Cycle and Atmospheric $\mathrm{CO}_{2}$ : Natural Variations Archean to Present. Am. Geophys. Union, Washington, D.C., pp.504-529. (Geophys. Monogr., 32.)

Aubry, M.-P., Berggren, W. A., Kent, D. V., Flynn, J. J., Klitgord, K. D., Obradovich, J. D. and Prothero, D. R., 1988. Paleogene geochronology: An integrated approach Paleoceanography, 3: 707-742.

Barron, E. J., 1987. Eocene equator-to-pole surface ocean 
temperatures: A significant climate problem? Paleoceanography, 2: 729-739.

Berger, W. G., Vincent, E. and Thierstein, H. G., 1981. The deep-sea record: Major steps in Cenozoic ocean evolution. In: J. E. Warme, R. G. Douglas and E. L. Winterer (Editors), The Deep Sea Drilling Project, A Decade of Progress. Soc. Econ. Paleontol. Mineral. Spec. Publ., 32: 489-504.

Berggren, W. A. and Hollister, C. D., 1977. Plate tectonics and paleocirculation - commotion in the ocean. Tectonophysics, 38: $11-48$

Berggren, W. A., Kent, D. V., Flynn, J. J. and Van Couvering, J. A., 1985. Cenozoic geochronology. Geol. Soc. Am. Bull., 96: $1407-1418$.

Berner, R. A., Lasaga, A. C. and Garrels, R. M., 1983. The carbonate-silicate geochemical cycle and its effect on atmospheric carbon dioxide over the past 100 million years. Am. J. Sci., 283: 641-683.

Brass, G. W., Southam, J. R. and Peterson, W. H., 1982. Warm saline bottom water in the ancient ocean. Nature, 296: 620-623.

Butler, R. F., Gingerich, P. D. and Lindsay, E. H., 1981. Magnetic polarity stratigraphy and biostratigraphy of Paleocene and lower Eocene continental deposits, Clarks Fork Basin, Wyoming. J. Geol., 89: 299-316.

Butler, R. F., Krause, D. W. and Gingerich, P. D., 1987. Magnetic polarity stratigraphy and biostratigraphy of middle-late Paleocene continental deposits of south-central Montana. J. Geol., 95: 647-657.

Caress, D. W., Menard, H. W. and Hey, R. N., 1988. Eocene reorganization of the Pacific-Farallon spreading center north of the Mendocino fracture zone. J. Geophys. Res., 93: 2813-2838.

Covey, C. and Barron, E., 1988. The role of ocean heat transport in climatic change. Earth-Sci. Rev., 24: 429-445.

Gingerich, P. D., 1980. Evolutionary patterns in early Cenozoic mammals. Annu. Rev. Earth Planet. Sci., 8: 407-424.

Gingerich, P. D., 1987. Evolution and the fossii record: Patterns, rates, and processes. Can. J. Zool., 65: 1053-1060.

Gingerich, P. D., 1989a. New earliest Wasatchian mammalian fauna from the Eocene of northwestern Wyoming: Composition and diversity in a rarely sampled high-floodplain assemblage. Univ. Mich. Pap. Paleontol,, 28: 1-97.

Gingerich, P. D., 1989b. Body size of Paleocene-Eocene Coryphodon and other large land mammals in relation to global temperature change. Geol. Soc. Am. Abstr. with Programs, 21 (6): 113-114.

Haq, B. U., Premoli-Silva, I. and Lohmann, G. P., 1977. Calcareous plankton paleobiogeographic evidence for major climatic fluctuations in the early Cenozoic Atlantic Ocean. J. Geophys. Res., 82: 3861-3876.

Haq, B. U., Hardenbol, J. and Vail, P. R., 1987. Chronology of fluctuating sea levels since the Triassic. Science, 235: $1156-1166$.

Hayes, D. E. and Pitman, W. C., III, 1970. Magnetic lineations in the North Pacific. In: J. D. Hays (Editor), Geological Investigations of the North Pacific. Geol. Soc. Am. Mem., 126: $291-314$.

Hubbard, R. N. L. B. and Boulter, M. C., 1983. Reconstruction of Palaeogene climate from palynological evidence. Nature, 301: $147-150$.
Janecek, T. R., 1985. Eolian sedimentation in the northwest Pacific Ocean: A preliminary examination of the data from Deep Sea Drilling Project Sites 576 and 578. In: G. R. Heath, L. H. Burckle et al., Initial Reports of the Deep Sea Drilling Project, 86. U.S. Government Printing Office, Washington, D.C., pp.589-603.

Janecek, T. R. and Rea, D. K., 1983. Eolian deposition in the northeast Pacific Ocean: Cenozoic history of atmospheric circulation. Geol. Soc. Am. Bull., 94: 730-738.

Keigwin, L., 1982. Isotopic paleoceanography of the Caribbean and East Pacific: Role of Panama uplift in late Neogene time. Science, 217: 350-353.

Kennett, J. P., 1977. Cenozoic evolution of antarctic glaciation, the circum-Antarctic ocean, and their impact on global paleoceanography. J. Geophys. Res., 82: 3843-3860.

Kennett, J. P. and Stott, L. D., 1989. Warm saline bottom water in early-middle Eocene: Isotopic evidence from Antarctica. Trans. Am. Geophys. Union (EOS), 70: 363.

Kutzbach, J. E., Guetter, P. J., Ruddiman, W. F. and Prell, W. L., 1989. The sensitivity of climate to late Cenozoic uplift in southeast Asia and the American southwest: Numerical models. J. Geophys. Res., 94, in press.

Leinen, M., 1987. The origin of paleochemical signatures in North Pacific pelagic clays: Partitioning experiments. Geochim. Cosmochim. Acta, 51: 305-319.

Leinen, M. and Stakes, D., 1979. Metal accumulation rates in the central equatorial Pacific during Cenozoic time. Geol. Soc. Am. Bull., 90 (1): 357-375.

Lyle, M. W., Owen, R. M. and Leinen, M., 1986. History of hydrothermal sedimentation at the East Pacific Rise, $19^{\circ} \mathrm{S}$. In: M. Leinen, D. K. Rea et al., Initial Reports of the Deep Sea Drilling Project, 92. U.S. Government Printing Office, Washington, D.C., pp.585-596.

Lyle, M., Leinen, M., Owen, R.M. and Rea, D. K., 1987. Late Tertiary history of hydrothermal deposition at the East Pacific Rise: Correlation to volcano-tectonic events. Geophys. Res. Lett., 14: 595-598.

Miller, K. G., Janecek, T. R., Katz, M. and Keil, D. J., 1987. Abyssal circulation and benthic foraminiferal changes near the Paleocene/Eocene boundary. Paleoceanography, 2: 741-761.

Oberhansli, H. and Toumarkine, M., 1985. The Paleogene oxygen and carbon isotope history of Sites 522, 523, and 524 from the central South Atlantic. In: K. J. Hsü and H. J. Wissert (Editors), South Atlantic Paleoceanography. Cambridge Univ. Press, Cambridge, pp.125-147.

Olivarez, A. M. and Owen, R. M., 1989. Plate tectonic reorganizations: Implications regarding the formation of hydrothermal ore deposits. Mar. Mining, 14: 123-138.

Owen, R. M. and Rea, D. K., 1985. Sea floor hydrothermal activity links climate to tectonics: The Eocene $\mathrm{CO}_{2}$ greenhouse. Science, 227: 166-169.

Prell, W. L., 1982. Oxygen and carbon isotopic stratigraphy for the Quaternary of Hole 502B: Evidence for two modes of isotopic variability. In: W. L. Prell, J. V. Gardner et al., Initial Reports of the Deep Sea Drilling Project, 68. U.S. Government Printing Office, Washington, D.C., pp.455-464.

Prentice, M. L. and Matthews, R. K., 1988. Cenozoic icevolume history: Development of a composite oxygen-isotope record. Geology, 16: 963-966. 
Rea, D. K. and Dixon, J. M., 1983. Late Cretaceous and Paleogene tectonic evolution of the North Pacific Ocean. Earth Planet. Sci. Lett., 65: 145-166.

Rea, D. K. and Leinen, M., 1986. Neogene controls on hydrothermal activity and paleoceanography of the southeast Pacific Ocean. In: M. Leinen, D. K. Rea et al.. Initial Reports of the Deep Sea Drilling Project, 92. U.S. Government Printing Office, Washington, D.C., pp.597-617

Rea, D. K. amd Schrader, H., 1985. Late Pliocene onset of glaciation: Ice rafting and diatom stratigraphy of North Pacific DSDP cores. Palaeogeogr. Palacoclimatol. Palaeoecol., 49: 313-325.

Rea, D. K. and Vallier, T. L.. 1983. Two Cretaceous volcanic episodes in the western Pacific Ocean. Geol. Soc. Am. Bull., 94: $1430-1437$

Rea, D. K., Leinen, M. and Janecek, T. R., 1985. Geologic approach to the long-term history of atmospheric circulation. Science, 227: 721-725.

Rea. D. K.. Dehn, J.. Driscoll. N. W., Janecek, T. R., Owen, R. M., Pospichal, J. J., Resiwati, P. and the ODP Leg 121 Scientific Party, 1990. Paleoceanography of the eastern Indian Ocean from ODP Leg 121 drilling on Broken Ridge. Geol. Soc. Am. Bull., 102. 679-690.

Rich, J. E., Johnson, G. L., Jones, J. E. and Campsie, J., 1986. A significant correlation between fluctuations in seafloor spreading rates and evolutionary pulsations. Paleoceanography. 1: $85 \cdots 95$.

Roberts. D. G., Morton, A. C. and Backman. J., 1984. Late Paleocene-Eocene volcanic events in the northern North Atlantic Ocean. In: D. G. Roberts, D. Schnitker et al., Initial Reports of the Deep Sea Drilling Project, 68. U.S. Government Printing Office, Washington, D.C.. pp.913-923.

Rona, P. A. and Richardson. E. S., 1978. Early Cenozoic global plate reorganization. Earth Planet. Sci. Lett., 40: 1-11.

Ronov. A. B., Khain, V. and Balukhovskiy, A. N.. 1978. Paleogene lithologic associations of the world. Sov. Geol., 3: $10-42$.

Rose, K. D., 1981. The Clarkforkian land-mammal age and mammalian faunal composition across the Paleocene-Eocene boundary. Univ. Mich. Pap. Paleontol., 26: 1-197.

Ruddiman. W. F. and Kutzbach, J. E., 1989. Forcing of late Cenozoic Northern Hemisphere climate by plateau uplift in southeast Asia and the American west. J. Geophys. Res.. 94: $18,409-18,427$.

Scotese, C. R., Gahagan, L. M. and Larson, R. L., 1988. Plate tectonic reconstructions of the Cretaceous and Cenozoic ocean basins. Tectonophysics, 155: 27-48.

Shackleton. N. J.. 1986. Paleogene stable isotope events. Palaeogeogr. Palaeoclimatol. Palaeoecol., 57: 91-102.

Shackleton, N. J., 1987. The carbon isotopic record of the Cenozoic: History of organic carbon burial and of oxygen in the ocean and atmosphere. In: J. Brooks and A. J. Fleet (Editors), Marine Petroleum Source Rocks. Geol. Soc. (London) Spec. Publ., 26: 423-434.

Shackleton, N. and Boersma, A., 1981. The climate of the Eocene ocean. J. Geol. Soc. Lond., 138: 153-157.

Shackleton, N. J. and Hall, M. A., 1984. Carbon isotope data from Leg 74 sediments. In: T. C. Moore, Jr., P. D. Rabinowitz et al., Initial Reports of the Deep Sea Drilling Project, 74. U.S. Government Printing Office, Washington, D.C. pp.613-619.
Shackleton. N. J., Backman, J., Zimmerman, H., Kent, D. V., Hall, M. A., Roberts, D. G., Schnitker, D., Baldauf, J. G., Desprairies, A., Homrighausen, R., Huddlestun, P., Keene, J. B., Kaltenback, A. J., Krumsiek, K. A. O., Morton, A. C., Murray, J. W. and Westberg-Smith, J., 1984a. Oxygen isotope calibration on the onset of ice-rafting and history of glaciation in the North Atlantic region. Nature. 307: $620-623$.

Shackleton. N. J., Hall. M. A. and Boersma, A., 1984b. Oxygen and carbon isotope data from Leg 74 foraminifers. In: T. C. Moore, Jr., P. D. Rabinowitz et al., Initial reports of the Deep Sea Drilling Project, 74. U.S. Government Printing Office, Washington, D.C., pp.599-612.

Shackleton, N. J. Hall, M. A. and Bleil, U., 1985. Carbonisotope stratigraphy, Site 577. In: G. R. Heath, L. H. Burckle et al., Initial Reports of the Deep Sea Drilling Project, 86. U.S. Government Printing Office, Washington, D.C., pp. $503-511$.

Sloan, L. C. and Barron, E. J., 1989. Eocene climate based on results from atmospheric general circulation model experiments. Trans. Am. Geophys. Union (EOS), 70: 374-375.

Stott, L. D., Kennett, J. P., Shackleton, N. J. and Corfield, R. M., in press. The evolution of Antarctic surface waters during the Paleogene: Inferences from the stable isotopic composition of planktonic foraminifera. Proc. Ocean Drilling Program, 113

Thiede, J., Agdestein. T. and Strand, J. E., 1980. Temporal and spatial variations of the upper Mesozoic and Cenozoic sediment flux to the deep North Atlantic Ocean. Mar. Geol, 36: MI1-M19.

Thiede, J.. Strand, J. E. and Agdestein, T., 1981. The distribution of major pelagic sediment components in the Mesozoic and Cenozoic North Atlantic. In: J. E. Warme, R. G. Douglas and E. L. Winterer (Editors), The Deep Sea Drilling Project: A Decade of Progress. Soc. Econ. Paleontol. Mineral. Spec. Publ., 32: 67-90.

Thomas, E.. in press. Mass extinctions in the deep sea. In: Global Catastrophes in Earth History. Geol. Soc. Am. Spec. Publ., in press.

Thunell. R. C. and Williams, D. F., 1983. The stepwise development of Pliocene-Pleistocene paleoclimatic conditions in the Mediterranean: Oxygen isotopic studies of DSDP sites 125 and 132. In: J. E. Meulenkamp (Editor), Reconstruction of Marine Paleoenvironments. Utrecht Micropaleontol. Bull., 30: 111-127.

Tjalma, R. C. and Lohmann, G. P., 1983. Paleocene-Eocene bathyal and abyssal benthic foraminifera from the Atlantic Ocean. Micropaleontol. Spec. Publ. 4, 90 pp.

White, R. S. and McKenzie, D. P., 1989. Magmatism at rift zones: The generation of volcanic continental margins and flood basalts. J. Geophys. Res., 94: 7685-7729.

Wolfe, J. A., 1978. A paleobotanical interpretation of Tertiary climates in the Northern Hemisphere. Am. Sci., 66: 694-703.

Wolfe, J. A., 1989. North American Eocene vegetation and its climatic implications. Trans. Am. Geophys. Union (EOS). 70: 375 .

Woodruff, F. and Savin, S. M., 1989. Miocene deepwater oceanography. Paleoceanography, 4: 87-140.

Zachos, J. C., Arthur, M. A., Thunell, R. C., Williams, D. F. and Tappa, E. J.. 1985. Stable isotope and trace element 
geochemistry of carbonate sediments across the Cretaceous/Tertiary boundary at Deep Sea Drilling Project Hole 577, Leg 86. In: G. R. Heath, L. H. Burckle et al., Initial Reports of the Deep Sea Drilling Project, 86. U.S. Government Printing Office, Washington, D.C., pp.513-532.

Zachos, J. C., Arthur, M. A. and Dean, W. E., 1989. Geochemical evidence for suppression of pelagic marine productivity at the Cretaceous/Tertiary boundary. Nature, 337: 61-64.

Zachos, J. C., Breza, J., Wise, S., Kennett, J., Stott, L. and the ODP Leg 120 Shipboard Scientific Party, 1989b. A high latitude, southern Indian Ocean, Middle Eocene to Oligocene paleoclimatic record. Trans. Am. Geophys. Union (EOS), 70: 375 . 